EVOLUTION OF A MODEL

\title{
A Methodological Approach to Designing a Theory: The Journey of the Four Zone Professional Learning Model
}

\author{
Angela M. Novak ${ }^{1}$ and Katie D. Lewis ${ }^{2}$ \\ ${ }^{1}$ Department of Elementary and Middle Grades Education, College of Education, East Carolina \\ University \\ ${ }^{2}$ Department of Education, School of Behavioral Sciences and Education, York College of \\ Pennsylvania
}

Author Note:

Angela M. Novak (Dhttps://orcid.org/0000-0002-8257-4731

Katie D. Lewis (Dhttps://orcid.org/0000-0003-1398-5673

Posted as a preprint to edarxiv 2/16/21: 10.35542/osf.io/a97vm

Correspondence concerning this article should be addressed to Angela Novak, Speight 311, Mailstop 504, East Carolina University Greenville NC 27858. Email: novaka17@ecu.edu. 
EVOLUTION OF A MODEL

\begin{abstract}
The Four Zone Professional Learning Model is a practical, comprehensive approach to striving towards equity through professional learning within gifted education programs. Grounded in equity literacy and funds of knowledge frameworks and based in best practices in culturally responsive gifted professional learning, the zones address the knowledge and skills necessary for proficient teachers of the gifted through the process of systemic change. The model was designed and developed over several years utilizing the plan-study-do-act action research model. This article discusses the methodological evolution of the model, the research and theoretical frameworks in which it is grounded, and future implications.
\end{abstract}

Keywords: professional learning, equity, action research, gifted, theoretical model 
EVOLUTION OF A MODEL

\section{A Methodological Approach to Designing a Theory: The Journey of the Four Zone Professional Model}

Disparities exist within gifted education. Opportunity gaps in recognition, identification, and retention of culturally, linguistically, and economically diverse gifted learners. In 2011, the National Association for Gifted Children (NAGC) released a position statement charging educators, policy makers and researchers to examine all aspects of gifted programming to specifically address the needs of underrepresented populations and to identify best practices and funding to ensure the need of culturally, linguistically, economically, diverse (CLED) gifted populations are being met. Suggestions on how to achieve equilibrium have been posed, evaluated, and reevaluated resulting in recommendations on how to address these inequities. Yet, these disparities still exist. This is in part due to the piecemeal approach for affecting change in education; systemic change requires all components of the gifted education system to be evaluated and altered. It requires a recognition not just of problems of identification or programs, but of the oppression, the racism, and the bias that exists in the fabric of the nation's school systems at large. Identification measures need to address anti-blackness. Program offerings need to trace their history to settler colonialism. Teachers, mentors and peer groups need to be culturally responsive. Educators need to be aware of these overlapping systems of oppression that are intentionally excluding gifted students of color. Adjusting only one part of the gifted education system for equity perpetuates inequity; like cogs and gears, if one part is jammed, the wheels cannot move.

It was with this premise in mind that in 2013 the authors began to explore underrepresentation of Hispanic bilingual gifted students. Findings showed that in a learning environment that was $98 \%$ Hispanic and with teacher demographics reflective of the student 
EVOLUTION OF A MODEL

body, there was still a significant disproportionality of Hispanic bilingual gifted students participating in gifted programming (Lewis, et al., 2015a). The need for systemic change in gifted education was clear, though the authors debated how long-term positive change could be initiated and sustained. Based on a review of literature, they decided to start with teachers.

Good teachers are made, not born. This is the foundation for the need for high quality professional learning (Darling-Hammond et al., 2009). There is a long history in the field of education for the need for continued learning among educators seeking to be the model of lifelong learning for those they teach. The positive effects of professional learning on changing teacher practice and mindset solidified its value (Brigandi et al., 2019; Dixon et al., 2014; Kronborg \& Plunkett, 2013; Miller, 2009; Peters \& Jolly, 2018).

The Four Zone Professional Model provides a structure for providing systemic change to gifted education (Novak \& Lewis, 2015; Lewis \& Novak, 2019a; Novak \& Lewis, 2021). The first zone seeks to raise awareness of the inequities in student populations through targeted professional learning. This is the beginning equity work: understanding the self, understanding the community, understanding the system. Paul Gorski (personal communication, November 14, 2019) shares that you cannot start a discussion with IF the question of racism exists in the space, but by naming how it does. If you have to start by debating the IF, the organization has miles to go before they are ready to start the equity work. The second zone connects culture to the manifestation of giftedness as well as the impact of systemic inequities on a student's educational experience. The third zone focuses on ways to provide support to teachers and students before and after identification to mitigate and provide reparations against these inequities. Finally, the fourth zone focuses on making connections with the families and communities of the marginalized populations (Lewis \& Novak, 2019b). The zones are meant to 
EVOLUTION OF A MODEL

be cycled through in an iterative process, as the teachers need more professional learning in various topics, thus creating a rotation of ongoing support leading to systemic change. The original Four Zone Model and the Three-Prong Model before that had more of a cultural focus (see Figure 1) while the latest iteration centers on equity terminology (see Figure 2). In this manuscript "culture" is operationalized as culturally, linguistically, and economically diverse.

\section{Figure 1}

Four Zones of Professional Learning

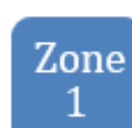

- Increasing Educator's Understand of Cultural Norms

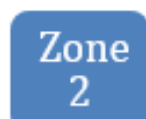

- Increasing Educator's Understanding of Characteristics of Gifted CLED Students

\section{Zone}

3

Zone

4
- Increasing Classroom Support for Educators and Gifted CLED Students

- Increasing and Developing Partnerships with CLED Parents and the Community

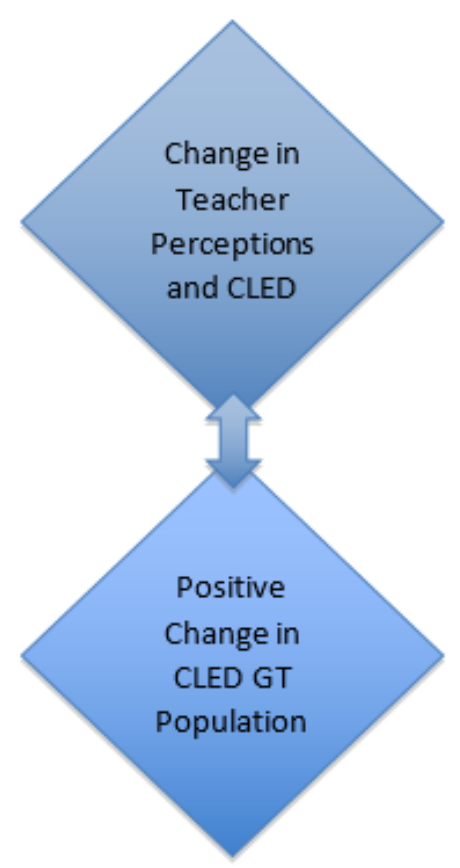

Note: (Lewis \& Novak, 2019a) Reprinted with permission from Prufrock Press. 
EVOLUTION OF A MODEL

\section{Figure 2}

Four Zone Equity- Driven of Professional Learning Model, Updated

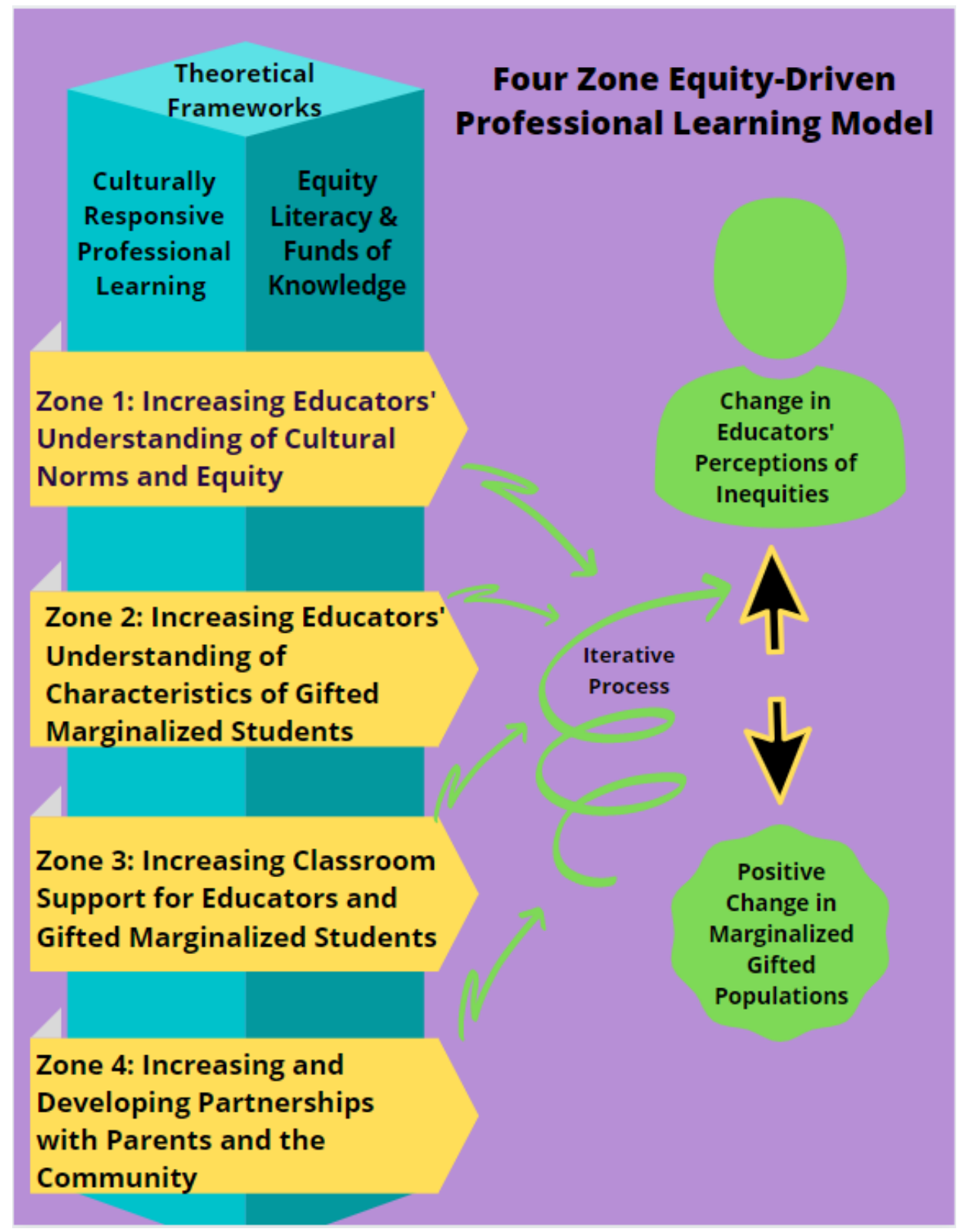

Note: Novak \& Lewis, 2021; reprinted with permission from the authors.

The Model has been developed through a recursive process of research, feedback, reflection, and growth using the plan-do-study-act cycle (Moen \& Norman, 2010) from 2015 through its current iteration, in 2021 (see Figure 2). It is grounded in gifted education, culturally responsive 
EVOLUTION OF A MODEL

professional learning and equity theoretical frameworks and offers a systematic approach to address the inequities present in gifted programs fostered by longstanding oppression, bias and racism.

\section{Theoretical Frameworks}

The Four Zone Professional Learning Model is framed in literature related to culturally responsive professional learning and equity. The following section is an in-depth discussion of each of these core areas.

\section{Culturally Responsive Professional Learning in Gifted Education}

Professional learning has evolved from one day workshops to sustained data driven sessions uniquely tailored to the needs of a group of teachers. Every Student Succeeds Act (ESSA) is the current federal legislation that guides K-12 educational policy in the United States. ESSA recognizes the significant role professional learning in schools as it is related to student outcomes, achieving equity and inclusivity within schools, part of the continuous cycle of learn, play, do, assess, modify, repeat and always data driven (Alexander, 2018). The focus on professional learning for educators within ESSA signifies the critical role of teachers on all aspects of student success in K-12 schools. Professional learning activities are fundamental strategies for providing all educators with knowledge and skills to meet the needs of all learnersacademic as well as social-emotional, which are "sustained, intensive, collaborative, jobembedded, data-driven, and classroom-focused" (ESSA, Section 8101(42 A-B).

Professional learning encompasses a wide variety of learning environments and experiences in which teachers, administrators, and other school district personnel further develop knowledge and skills related to their craft. The most effective professional learning is sustained and intensive with an in-depth exploration, approximately fifty hours of the topic (Darling- 
EVOLUTION OF A MODEL

Hammond et al., 2009). Sustained, in-depth professional learning allows teachers the opportunity to learn, implement the new practice, reflect and gather feedback, and modify. Without this opportunity to explore the new practice, teachers are less likely to experience long term benefits from the professional learning (Gulamhussein, 2013). Professional learning should be connected to practice within the classroom and provides opportunities for collaboration amongst colleagues (Darling-Hammond et al., 2009; Gulamhussein, 2013). Coaching and support during the implementation of the new practice are critical to the success of the teacher. Without a support system, the teachers are more likely to revert to tried and true routines and practices. Ironically, the best practices of teaching pedagogy are not always applied during professional learning sessions. Rather, teachers are expected to 'sit and get' rather than be actively involved (Gulamhussein, 2013). Professional learning which engages teachers in the same best practices of instructional delivery are significantly more effective in changing teachers' mindsets and beliefs. Modeling is an effective way for teaching a new practice (Gulamhussein, 2013). Using the inquiry-based methodology, teachers explore the instructional practice or concept, thus forming their own understanding of the topic. Instead of generic one size fits all models for professional learning, the facilitators should carefully craft the sessions to focus on the needs of the specific group (Gulamhussein, 2013), which will result in more productive outcomes.

NAGC echoes the research-based recommendations (Darling-Hammond et al, 2009; (Gulamhussein, 2013) as well as government policy (ESSA): research-based, job-embedded, classroom applications, ongoing cycle of reflection and feedback (National Association for Gifted Children, 2019) in the Pre-K-Grade 12 Gifted Education Programming Standards. The newly revised standards are based on theory, research and best-practices for all aspects of gifted education and establish common practices for the field in six areas. Standard 6 focuses on 
EVOLUTION OF A MODEL

Professional Learning, which is divided into five student-outcome areas aligned with evidencebased practices for high quality professional learning for educators of the gifted. StudentOutcome 6.3, Equity and Inclusion states "all students with gifted and talented are able to develop their abilities as results of educators who are committed to removing barriers to access and creating inclusive gifted communities" (National Association for Gifted Children, 2019, p.

2). Three evidence-based teacher practices are identified:

- 6.3.1 Educators participate in professional learning focused on curriculum and pedagogy that are responsive to diversity for individuals with gifts and talents.

- 6.3.2 Educators recognize their biases, develop philosophies responsive to diversity, commit themselves to removing barriers, and create inclusive learning environments that meet the educational interests, strengths, and needs of diverse students with gifts and talents.

- 6.3.3: Educators understand how knowledge, perspectives, and historical and current issues influence professional practice and the education and treatment of individuals with gifts and talents both in school and society. (National Association for Gifted Children, 2019, p. 2).

Professional learning focused on gifted education is often limited in school districts.

Traditionally, professional learning for gifted education centered on the basics of gifted education: common characteristics or behaviors of gifted students, the procedures for referrals and the identification process for the school district, and differentiation or teaching strategies. Even these workshops focused on the basics of gifted education are not standardized and vary greatly by state, district and local levels. In some cases, gifted professional learning is only provided to the gifted specialists and never to the general education classroom teacher. Yet, a 
EVOLUTION OF A MODEL

reality of many gifted education programs is that gifted students often spend more time in the general education classroom than classes dedicated solely to advanced learning. Additionally, classroom teachers are often the first point of contact for referrals and the identification process. Therefore, it is imperative that general education classroom teachers receive adequate professional learning on all aspects of gifted education. The cycle of reflection in professional learning is essential to growth over time- not only in instructional practices but also a change in teacher belief systems. The success of professional learning in changing teachers' mindsets and beliefs related to characteristics of giftedness, curriculum and instruction has been reported in the literature (Dixon et al., 2014; Kronborg \& Plunkett, 2013; Miller, 2009; Peters \& Jolly, 2018). Positive effects of professional learning decrease when it is not on going.

Teachers benefit the most from regular professional learning which focuses on the following five areas: characteristics and behaviors of underrepresented populations, cultural awareness, twice exceptional characteristics, fostering positive peer culture and unbiased identification assessments (National Association for Gifted Children, n.d.). Professional learning provides the opportunity to grow teachers' understanding of equity and culture on student achievement. This is particularly important in the gifted education, which historically has not been an accurate representation of the total student population.

\section{Culturally Responsive Professional Learning}

Historically, gifted education has underserved marginalized student populations. In 201314, about seven percent of the total US student population were enrolled in gifted and talented programs. Students identified as White (7.7\%) and Asian (13.3\%) made up the majority of those who were enrolled in gifted programs. These numbers reflect the traditional understandings of giftedness as well as the stereotype that all Asians are gifted. The disparities of gifted education 
EVOLUTION OF A MODEL

can be seen within the ethnic breakdown of students: $4.3 \%$ Black, $4.9 \%$ Hispanic, $4.4 \%$ Pacific

Islander, 5.2 American Indian/Alaska Native, two or more races 6.9\% (National Center for

Education Statistics (NCES), 2018). The disparity is more evident when you look at the numbers

as times more likely- by dividing the percentage of students identified by comparative groups, for

example, students identified as White are 1.79 times more likely to be enrolled in gifted

programs than students identified as Black. NCES divides Asian and Pacific Islander as two

ethnicity subgroups, rather than grouping them together. The 2013-14 data indicates that students

identified as Asian are 3.02 times more likely to be enrolled in gifted programs than those identified as Pacific Islanders.

Schools in the United States reflect the growing diversity of our nation, while the administrations and teachers often lack the same diversity (Partelow et al., 2017). With the changing demographics, it is necessary to include professional learning which addresses cultural agility in teaching and learning and explores the cultural capital and assets of students, as well as community assets, and the depth and breadth of how these elements are infused throughout the classroom environment, student-teacher interactions, and the learning processes. Lifelong knowledge acquisition is a tenet of professional learning, yet, often learning is often absent of conversations regarding cultural considerations. Culturally responsive professional learning is "grounded in the research on teacher learning that is mindful of the role culture plays in the knowledge that educators bring to their practice, as well as how educators learn and make sense of their daily practice" (King et al., 2009, p. 5). Equity-driven professional learning within the field of gifted education needs to be infused with cultural agility, understanding and reflection; the authors developed the Seven Guiding Principles for Developing Equity-Driven Professional Learning (2020; see Table 1) in order to meet this need. 
EVOLUTION OF A MODEL

Table 1

Guiding Principles in Equity-Driven Professional Learning for Educators of Gifted Students

\begin{tabular}{l|l} 
Guiding Principle & \\
\hline Taking a Pulse
\end{tabular}

Description

Taking a Pulse

- Pre-assess the faculty to determine prior knowledge and areas of strengths and weakness

- Use the data to guide the professional learning sessions

- Use ongoing formative assessment

Individualizing Professional Learning Plans

- Use the pre-assessment data, create individualized professional learning plans for teachers and staff

- Vary the length and speed of the learning sessions for teachers and staff

Establishing a Safe Zone

Going Beyond the Tip of the Iceberg

- Establish guidelines for the professional learning sessions

- Develop trust and ensure confidentiality by setting appropriate boundaries

- Examine cultures and the importance of cultural awareness in the classroom

- Focus on characteristics of giftedness within the cultural context

Bridging the Gap between School and Home
- Establish ways to engage parents and communities in the school, especially regarding information and support for gifted learners

- Build teachers' cultural awareness of the parental and community perceptions towards gifted education

- Invite teachers to share what works well for them (strategies and tips); help make connections to cultural competency and best practices for gifted learners

- Encourage teachers to share areas where they have room to improve their craft and understanding of CLED gifted students

- Engage with teachers to move beyond misconceptions 
EVOLUTION OF A MODEL

Engaging in Courageous Conversations
- Ask the tough questions- growth occurs when one is challenged to question understandings

- Be respectful of others

- Allow time for processing; changes in beliefs and practices occur over time

Note. Adapted from Novak et al., 2020, p. 176-177

Knowledge about gifted education cannot be solely focused on deep understanding of content, rather knowledge should be interwoven with the cultural nature of learning. Teachers need to explore their own personal and professional cultural identities, in order to be cognizant of possible unintentional messages, behaviors, biases they may bring to the classroom. Professional learning which enables teachers to explore their own cultural identities along with recognizing the needs and strengths that their pupils of all cultural backgrounds bring to school should be a cornerstone of gifted education.

\section{Equity Frameworks}

The equity context of the Four Zone Professional Learning Model is informed by two principal theories: equity literacy and funds of knowledge. These theories were central to the authors' conceptualizations of equity when developing and revising the Model. While outside of gifted education, the theoretical work connects fluently with scholarly work conducted in the field of gifted studies and is grounded in working against the concept of deficit thinking. Goings and Ford (2018) published a content analysis of studies examining the intersection of race, poverty and giftedness; in this sample almost half of the scholarly articles exhibited a deficit thinking approach while writing about their sample population. For example, studies put the impetus for change on the students, suggesting that they need to better adapt to the situations or show more resilience- the deficit thinking approach. In a non-deficit view, sometimes called a strengths-based or dynamic view, the school's role in supporting students would be pushed.

Other deficit minded statements from the scholarly articles included stereotypical conclusions 
EVOLUTION OF A MODEL

drawn about the family structure and home lives of the students. Both the equity literacy (Gorski

\& Swalwell, 2015) and funds of knowledge (González et al., 2005) frameworks argue against the use of deficit minded practices, either through specific principles or embedded in the basic framework.

\section{Equity Literacy Framework}

Quite simply, equity literacy (Gorski \& Swalwell, 2015) centers equity. While understanding culture and being responsive to students' culture is a part of the solution, a myopic view of culture can cause advocates to lose sight of the bigger picture. Social justice is the ultimate goal, righting the injustices; fixing the systemic oppression and racism that have propagated a broken system of education for far too long. To do this, equity must be the center of the diversity conversation.

The Equity Literacy framework (Gorski \& Swalwell, 2015) is supported by abilities and guiding principles. The abilities are Recognize, Respond, Redress, and Cultivate and Sustain. Recognize: train yourself and others to see even slight representations of bias, oppression, discrimination, inequality, and inequity. Understand when you are perpetrating them, when you are hearing them, when you are observing them. Respond: be able to address, thoughtfully and equitably, forms of bias, oppression, discrimination, inequity, or inequality. Know how you would respond to instances and be able to respond should the opportunity arise. Redress: advocate against bias, oppression, discrimination, inequity, or inequality. Respond to interpersonal bias, as well as observe how social change happens in order to make positive changes in personal spheres of influence. Cultivate and Sustain: actively work towards creating bias- and discrimination-free communities that are equitable and anti-oppressive (Gorski \& Swalwell, 2015). 
EVOLUTION OF A MODEL

Equity literacy began with five principles, but over time these principles have evolved and grown. The most recent publication of the equity literacy cites seven principles:

1. Direct Confrontation: Name and confront, in any iteration, racism or oppression: interpersonal, cultural, institutional, or structural. "Equity"” approaches that fail to directly identify and confront inequity play a significant role in sustaining inequity" (Gorski, 2020, p.1).

2. Equity Ideology: Equity is not a list of tasks of a checklist of strategies to cross off, it is a framework or lens. It is a commitment for your school or organization. Focusing on quick fixes will not foster equity.

3. Prioritization: There has been a shift from the term minorities because groups have been minoritized by the system- the effort is not to classify the people, but to focus on the action by the system. Educators need to prioritize those students and families that, historically, have been minoritized, or not prioritized. Gorski suggests asking, "What impact is this going to have on the most marginalized students and families? How are we prioritizing their interests?" (2020, p. 1).

4. Redistribution: By altering inequitable policies in gifted education, educators and administrators can take a step towards this principle, but that is not where the movement ends. Redistribution refers to cultural, material, and social opportunity and access. Administrators not only need to change identification, but also work towards the oppressive culture that exists in the overall school culture, within and outside of gifted programming. "If we cannot explain how our equity initiatives redistribute access and opportunity, we should reconsider them" (Gorski, 2020, p. 1). 
EVOLUTION OF A MODEL

5. Fix Injustice, Not Kids: Injustice, not grit. Injustice, not resilience. Injustice, not social and emotional learning programs. Injustice not restorative practices. This principle of equity literacy asks advocates to put the emphasis of change on the oppressive systemic culture and the inequitable policies and conditions that exist, rather than on the marginalized students and families. Change the system to fit the kids, do not try to change the kids to fit the broken system.

6. One Size Fits Few: Researchers generalize. They gather data in order to make inferences back to the representative population. But when you have identity groups within your community, rather than using generalizable research, look to people in your space and place. No single group is identical when it comes to value systems, learning approaches, and/or communication. If educators or administrators follow a single cultural framework in their commitment to working with their community, it is likely to be based on assumptions and stereotypes, rather than equity.

7. Evidence-Informed Equity: Using evidence-informed practices is key in education, and that does not change in equity. This is two-fold; empirical research is important, of course, but as described in principle six, listening and responding to the community itself is essential. The students, families, and communities, and the stories told by those within the community is important evidence to consider in data-informed practices.

These final principles of equity literacy (Gorski, 2020), based so heavily on what the students, families, and community bring to the equity table, are entrenched in the rejection of deficit thinking, and embracing the assets or strengths of the families and the community. This ties closely into the second equity focused theoretical framework: the funds of knowledge (FoK).

\section{Funds of Knowledge Theoretical Framework}


EVOLUTION OF A MODEL

An anthropologist, an educational researcher, and a teacher walk into a school... it could be the start of a joke, but instead it is the start of an educational study that became a theoretical framework, widely used in both K-12 and higher education. The funds of knowledge framework grew from a pilot student of 10 teachers in 1990. The educational researcher, Moll (2005), states:

Schooling practices are always intricately related to broader issues of social class, ideology, and power...our work helps teachers perceive or define working-class or poor households and communities as containing important funds of knowledge. In addition, through our collaboration with teachers, we have established that these funds of knowledge represent bonafide resources for teaching and learning in classrooms. (p. 277) The FoK approach begins with forming social relationships with parents and families. This enables teachers to understand the funds of knowledge, the community support, that the families can bring into the classroom, but also how those funds of knowledge are represented in the homes. The anthropologist, González, shares:

Because the term culture is loaded with expectations of group norms and often-static ideas of how people view the world and behave in it, we purposely avoided reference to the idea of culture...Instead we focused on practices- what households actually do and how they think about what they do. In this way, we opened up a panorama of the interculturality of households, that is how households draw from multiple cultural systems and use these systems as strategic resources. (González et al., 2005, p. 10) Formal interviews were conducted by the researchers in their original study. In practice, the funds of knowledge approach uses interviews, but it can be more of a home visit approach than a structured interview. 
EVOLUTION OF A MODEL

Because of the focus on developing relationships, the teacher then has close personal knowledge of the strengths that the parent can bring into the classroom to share, either by bringing in examples that are relevant to the students in the class or by having family members share their work embedded in the lessons. From the educator standpoint, the bonds with the families through the home visits and the ability to integrate both student interests and family and community connections is an essential component of FoK. The teacher of the original triad, Amanti, states, "you can know the academic standards inside and out, and write the most creative lesson plans, but if positive, affirming, and mutually respectful relationships are not the norm in our classrooms, no learning will take place" (2005, p. 140).

\section{A Retrospective Evolution of a Model}

\section{The Need}

While conducting research in Texas (see Lewis, et al., 2015a; 2015b), the authors noted that teachers did not recognize the strengths of students with gifts and talents and were surprised to observe that this held true even when they were of similar linguistic and ethnic background to the teachers. What attention was paid, in their programs or professional learning experiences to multiculturalism or equity? Was the whitewashing of history and gifted characteristics so effective that it impacted those of similar ethnic and cultural backgrounds? The authors, without realizing it at first, began a journey of action research, Plan-Do-Study-Act, or PDSA (Moen \& Norman, 2010). The following section outlines a retrospective journey of the creation of the Model, through the PDSA cycle.

\section{Plan-Do-Study-Act}

PDSA is used as action research, a project planning tool, or a change model (Tague, 2005). The four main steps are Plan- recognize the potential for change, review data or research, 
EVOLUTION OF A MODEL

come up with steps or tasks; Do- test; follow the list of tasks or timeline of steps; Study-analyze the results of the test/plan/steps or collect data and evaluate what was learned through the implementation; and Act- move forward based on what was learned, since this is a cycle, forward motion may be used to adjust the next plan of action and repeat the PDSA steps, or a new change may be implemented (Moen \& Norman, 2010; Tague, 2005). The authors recognized the need for further research and began to investigate professional learning, gifted characteristics across cultures in more depth, and teacher training at both the pre-service and in-service levels. The need for the Model itself evolved out of this initial study and the literature indicating a gap in professional learning experiences in gifted education at the undergraduate level for pre-service teachers, and an equity gap in professional learning experiences for educators for the gifted.

In one content analysis of scholarly articles, Goings and Ford found that studies "acknowledged that current identification procedures are not adequate in identifying gifted students of color who come from low-socioeconomic households" (2018, p. 31). However, as Hallett and Venegas (2011) remarked in their study exploring access to Advanced Placement classes, "increasing access alone will not resolve the inequities experienced by students in many urban educational environments" (p. 485). A greater shift is needed.

An additional theme found in Goings and Ford's content analysis (2018) was a focus on individuals rather than the system. Throughout the scholarly articles, the researchers noted discussions centered on critiques of children or families instead of the broken system. Scholars argued that students should show more grit or resilience rather than focus on how schools foster oppressive learning environments for students of color. Professional learning experiences are too often focused on strategies and implementation of curriculum, but not who teachers were teaching and the importance of culturally relevant curriculum. Goings and Ford's content 
EVOLUTION OF A MODEL

analysis of scholarly studies found a theme of the strong influence of teachers on the success of students. "Findings indicated that teachers recognized and found ways to integrate students' home culture into school...as a result there was also some discussion regarding the need for teachers to become more culturally competent" (2018, p. 31).

Nor is professional learning focused on the systemic oppression and the need for equity (Novak \& Jones, 2020). Akin to Gorski's (2020) "Fix Injustice Not Kids" principle, the focus is on strategies not structural change. Gifted education is receiving band aids, not a treatment plan. The authors looked at the creation of a professional learning model as a potential way to move the dial on systemic change within a school or district, and cycle one began.

\section{PDSA Cycle One}

The need for the model emerged from original research as well as a review of the literature. The first Plan steps are described in detail in earlier sections of this paper; the authors conducted a study that identified a goal for future study: they put a plan into action and conducted a literature review to learn more. The literature review morphed into the Do step, creating a product.

Do. The first working data-based model (Novak \& Lewis, 2015) was the "Targeted Professional Development: Three Prong Approach” and it was focused specifically on Hispanic/Latinx and bilingual (for simplicity, Latinx will be used moving forward) gifted students. Other notable vocabulary differences include professional development, not learning, and prongs, not zones.

The first prong addresses the need for increased understanding of the Latinx culture. Within this prong, teachers explore the Latinx culture with the intention of learning about the characteristics of the culture, asking questions for greater understanding and learning to embrace 
EVOLUTION OF A MODEL

the culture. Prong two asks teachers to learn about the characteristics of Latinx bilingual gifted students. Having established an understanding of the Latinx culture, the next step is to explore how giftedness presents itself within the cultural group. This essential professional development prong facilitates the recognition of the traits of giftedness within the underserved population. The third prong addresses the need to increase classroom support for the gifted students, especially with regards to any needs as English Language Learners. Without support for the language learners within gifted programming, the identified gifted bilingual student may not be successful within the traditional gifted curriculum. This prong provides the professional development focused on providing support for language acquisition and learning opportunities in both Language 1 and Language 2. Additionally, professional development during prong 3 should focus on access resources to highlight students' dual language abilities utilizing best practices for English Language Learners (ELL) as well as networking opportunities with other educators who have expertise with ELL strategies.

Over the course of three years, the authors presented the Three Prong Approach at local, state and national gifted education conferences. The Do step involves creation and implementation, while the Study phase requires the action researchers to test the validity of the plan, review what happened, and discuss next steps.

Study. During the study step, the authors debriefed after each conference or professional learning event. They discussed the model in the context of professional learning as it was used as a model at conferences and events. Throughout both the Do and the Study steps, the authors continued to review literature, as well as attend conference sessions and professional learning initiatives to further their own knowledge on giftedness, professional learning, equity, antiracism, cultural responsiveness, and other related topics. During this time period, one of the 
EVOLUTION OF A MODEL

authors began working on culturally responsive professional learning principles that were later incorporated into the zones (see Novak et al., 2020). They continued to adjust the presentation and the base Model throughout, though significant changes are described as part of the Act step.

Act. As the final step in the cycle, the goal of Act is to close the process, integrating learning, adjusting the goals as needed, possibly reformulating the theory or changing the scope of the focus. In some cases, the PDSA cycle is only one turn, and implementation of the change begins; in other cases, the Act step is followed by a subsequent Planning stage, and the iterative process renews. The authors continued to present the Model and make changes from 2015 to 2018 based on increased knowledge from their own professional learning and feedback from the sessions. Changes throughout 2015-2018 included: moving from professional learning for teachers designed to increase understanding of Latinx youth to promoting equity and access for all minoritized gifted youths; including more examples from representative cultures in the presentations; and adjusting the method of presentation and examples to make connections with the target audiences. The most significant change emerged in 2018, through a second cycle of PDSA.

\section{PDSA Cycle Two}

While most of the work, specifically the data collection and analysis of PDSA Cycle 1 went through 2018, the Planning cycle of PDSA Cycle 1 began at a national gifted conference in the fall of 2017. Lifelong learning is, by its very nature, iterative, and so the PDSA cycles sometimes overlap, without clear-cut starting and ending dates.

Plan. The authors attended several parent meetings at a national conference, being parents of gifted and twice exceptional gifted children themselves. Reflecting on the parent meetings and the importance of community, collectivism, and family in the culturally responsive 
EVOLUTION OF A MODEL

literature (Lewis et al., 2012), the authors revamped their Model to incorporate an additional prong (now termed zones). The fourth zone is largely informed by the funds of knowledge theoretical framework, though there are ties to culturally responsive teaching and equity literacy. At this point, they also made the shift to professional learning from development.

Do. The Targeted Professional Learning: Four Zone Approach (see Figure 1) as it is now known (see Figure 2) was born in Cycle 2, Do, with an updated phrasing and graphics as recently as 2021. The newly dubbed Zone 1: Increasing Educators' Understanding of Cultural Norms and Equity and Zone 2: Increasing Educators' Understanding of Characteristics of Gifted Marginalized Students remained in-name more or less the same as the original Three Prong Approach Model. However, there was an emphasis on first recognizing the role a teacher's own culture played in their interactions with students in the classroom, and a need for an understanding of the cultural groups within the school. After establishing a solid foundation of recognizing the self, understanding one's own biases and culture, and recognizing the strengths and assets of others, within and around the school, the second zone overlays this cultural knowledge on giftedness, exploring how giftedness presents within diverse student populations.

The third zone: Increasing Classroom Support for Educators and Gifted Marginalized Students focuses on providing instructional and social emotional support to diverse gifted learners and educators, both before and during gifted identification and enrollment in the gifted program. Previously, this area focused on language supports, and then general instructional supports, but always had a focus on both supports both prior to and after identification, especially as the Model evolved after it was first presented. Greater attention is given to frontloading and support prior to identification in the revised Model, and more focus is devoted to equity-driven scaffolding both in recruitment and retention of children of color in gifted 
EVOLUTION OF A MODEL

programs. Professional learning during this zone is necessary to ensure that both the teachers and learners have a system of support to ensure success within the gifted program. The fourth zone: Increasing and Developing Partnerships with Parents and the Community was added in the new Model; it focuses on parent and community involvement. This fourth zone extends the partnership between schools and communities, establishing an open relationship where cultural groups are able to ask questions, explore, acknowledge and build upon cultural strengths.

Titular changes in the second iteration of the Model include zones and professional learning. The change from prongs to zones reflects the cyclical nature of learning. Zones are fluid spaces where one may alter course based on individualized needs. For example, a professional learning session may focus on Zone 3, yet when the facilitator or educator recognizes a gap in understanding, the session can change course to include Zone 2 as well. Likewise, a change in teacher perceptions regarding marginalized students leads to a positive change in the marginalized gifted population and vice versa. The change in professional learning is responsive to the movement in the education field. This naming shift supports the transition from "one and done" workshops to ongoing, sustained, collaborative experiences that honor adult learners and provide job-embedded experiences (Weber et al., 2018).

The newly revised Four Zone Model was presented to peers at conferences for feedback (see, Novak \& Lewis, 2018; Novak \& Lewis, 2019), and published as a chapter (Lewis \& Novak, 2019a) as a theoretical model (see Figures 1 and 2). The culturally responsive professional learning principles, mentioned in Phase One, Study, were revised throughout this time period as well, presented in the winter of 2020, and published by the authors as the Guiding Principles in Equity-Driven Professional Learning for Educators of Gifted Students in 2020. These principles are embedded within the Four Zones, as integral aspects of facilitating 
EVOLUTION OF A MODEL

professional learning experiences. Further action-oriented Do steps, the authors undertook two implementation studies, taking theory into practice in different environments, as invited speakers on the topics of gifted education and equity. This work leads directly into the Study step.

Study/Act. Making the connection from theory to practice, the next stage of PDSA requires the implementation of the Model in a real-world context. The fluidity of this model enables districts to modify it to fit their unique needs within the context of the district. For example, the district may choose to host virtual PL sessions during the upcoming academic year. In this sample, the gifted coordinator identified underrepresentation of Native American/Alaskan Native/Indigenous People (NAANIP) students in the district's gifted program. The first step would be to pre-assesses the teachers' perceptions of cultural understanding and manifestation of giftedness in the Native American population. Based on the current needs of her teachers, the coordinator would then develop quality professional learning modules tailored to the team, beginning with Zone 1.

Table 2 presents one possible layout for the professional learning cycle utilizing three differentiated Professional Learning Communities (PLCs) based on the needs of the educators along with selected resources for each zone. A PLC is a small group of educators, generally grouped by grade level or content area that engages in ongoing, sustained, collaborative, jobembedded, and reflective professional learning activities together. In this instance, the PLCs are created based on the pre-assessment. Table 2 provides three possible PLC groups. PLC 1 includes participants that demonstrated little to no cultural/equity awareness and shared several misconceptions related to gifted characteristics and NAANIP students in particular during the pre-assessment. PLC 2 includes teachers whose pre-assessment data indicated average cultural/equity awareness, but that also held misconceptions related to gifted characteristics 
EVOLUTION OF A MODEL

related to NAANIP groups in particular. PLC 3 is comprised of educators that, based on preassessment results, are culturally/equity aware and recognize how NAANIP students may exhibit gifted characteristics. Ideally, each PLC has a facilitator, but some groups can self-facilitate with detailed plans with guided questions and thoughtful reflective prompts. As noted in the literature review, ongoing feedback is ideal; a reflective notebook can be passed between a central facilitator and the PLC. The trained facilitator can provide ongoing feedback, pushing back on conversations when needed, and helping participants dig deeper beyond the tip of the iceberg, and honoring glows and counseling grows (see Table 1 for the Guiding Principles of Equity Driven Professional Learning). Keep in mind the professional learning should be fluid, allowing participants to move slower, faster, forwards or backwards based on individual needs-- both needs identified by the participant as well as the facilitator. Flexibility is essential when planning for professional learning as both internal and external barriers to learning and growth are often at play.

Table 2

Zones in Action: Sample Planning Chart

\begin{tabular}{|c|l|l|l|}
\hline Zone & \multicolumn{1}{|c|}{ PLC 1 } & \multicolumn{1}{c|}{ PLC 2 } & \multicolumn{1}{c|}{ PLC 3 } \\
\hline \multicolumn{2}{|c|}{ For each PLC and in all zones, include self-reflective journaling, discussions, and debriefs. } \\
\hline \begin{tabular}{c|l|l|l} 
Zone \\
$\mathbf{1}$
\end{tabular} & $\begin{array}{l}\text {-Understanding the self is } \\
\text { the first step of the journey: } \\
\text { facilitator and PLC must } \\
\text { unpack culture, unpack } \\
\text { Whiteness, discuss how the } \\
\text { participants' culture } \\
\text { influences their teaching } \\
\text { and classroom } \\
\text {-Discuss how systems of } \\
\text { oppression and bias are } \\
\text { seen in the school and }\end{array}$ & $\begin{array}{l}\text {-Based on the pre- } \\
\text { assessment, this group } \\
\text { likely has an initial } \\
\text { understanding of self and } \\
\text { culture. But understanding } \\
\text { the self is always the first } \\
\text { step of the journey, and } \\
\text { their work is the same as } \\
\text { PLC 1 in 'unpacking', } \\
\text { however the facilitator } \\
\text { should lead the discussion }\end{array}$ & $\begin{array}{l}\text {-Primary Facilitator } \\
\text { introduces the Funds of } \\
\text { Knowledge Framework } \\
\text { model. in a train the trainer } \\
\text {-Group members share the } \\
\text { Zone 1 facilitation role } \\
\text { with support from main } \\
\text { facilitator } \\
\text {-Primary Facilitator } \\
\text { provides supplemental }\end{array}$ \\
\hline
\end{tabular}


EVOLUTION OF A MODEL

\begin{tabular}{|c|c|c|c|}
\hline & $\begin{array}{l}\text { community and how these } \\
\text { impact NAANIP students } \\
\text { and families. Offer } \\
\text { scaffolding or examples to } \\
\text { start the conversation. } \\
\text {-Provide background } \\
\text { knowledge through } \\
\text { multiple modalities (MM) } \\
\text { about NAANIP in general, } \\
\text { providing a global } \\
\text { understanding of the ethnic } \\
\text { group and then narrowing } \\
\text { to populations found within } \\
\text { the district, community, and } \\
\text { school. Emphasize the } \\
\text { importance of not } \\
\text { generalizing but knowing } \\
\text { the community and } \\
\text { students. } \\
\text {-Guide discussion through } \\
\text { common misconceptions } \\
\text { and stereotypes of the } \\
\text { NAANIP group(s) in the } \\
\text { school, district, and } \\
\text { community. }\end{array}$ & $\begin{array}{l}\text { deeper, and focus on } \\
\text { privilege, on } \\
\text { intersectionality, and/or on } \\
\text { upstander vs. bystander. } \\
\text {-Again, it is important for } \\
\text { the facilitator to situate the } \\
\text { discussion with how racism, } \\
\text { oppression and bias } \\
\text { operates in this place and } \\
\text { space. This group based on } \\
\text { the pre-assessment should } \\
\text { have more detailed and/or } \\
\text { realistic examples and may } \\
\text { need less scaffolding to } \\
\text { think of them. } \\
\text {-Facilitator provides } \\
\text { specific deep knowledge } \\
\text { through multiple modalities } \\
\text { (MM) on NAANIP tribal } \\
\text { groups found within the } \\
\text { district, community, and } \\
\text { school. } \\
\text {-Facilitator introduces the } \\
\text { Funds of Knowledge (FoK) } \\
\text { Framework. }\end{array}$ & $\begin{array}{l}\text { knowledge through } \\
\text { multiple modalities (MM) } \\
\text { to extend knowledge on } \\
\text { giftedness, equity, and/or } \\
\text { NAANIP groups based on } \\
\text { the pre-assessment; } \\
\text { debriefs with facilitator in } \\
\text { small groups or one-on-one } \\
\text { depending on numbers. }\end{array}$ \\
\hline $\begin{array}{c}\text { Zone } \\
2\end{array}$ & \multicolumn{2}{|c|}{$\begin{array}{l}\text { Based on the pre-assessment, neither PLC } 1 \text { or } 2 \text { has a } \\
\text { solid understanding of giftedness in the NAANIP group. } \\
\text { Therefore, the activities in zone } 2 \text { are the same: } \\
\text {-Discuss the impact of systemic inequities on the students; } \\
\text { relate to gifted education. } \\
\text {-Present through MM and discuss: } \\
\text {---What does giftedness look like in the NAANIP } \\
\text { culture? } \\
\text {---How may giftedness present differently in the } \\
\text { classroom than what teachers expect? } \\
\text {-Use case studies and scenarios. Reflect on real-word } \\
\text { examples, making connections to students in the } \\
\text { classroom. Provide time for discussion and sharing } \\
\text { opportunities } \\
\text {-Provide opportunities for job-embedded } \\
\text { operationalization of the professional learning through } \\
\text { discussions of current students' profiles, making } \\
\text { connections to the Zone } 1 \text { \& } 2 \text { content. }\end{array}$} & $\begin{array}{l}\text {-PLC shares the Zone } 2 \\
\text { facilitation role with } \\
\text { support from facilitator } \\
\text {-Facilitator provides } \\
\text { supplemental knowledge } \\
\text { through multiple } \\
\text { modalities to extend } \\
\text { knowledge on giftedness, } \\
\text { equity, and/or NAANIP } \\
\text { groups; debriefs with PLC } \\
\text { in small groups or } 1: 1 \\
\text {-Primary facilitator } \\
\text { provides opportunities for } \\
\text { PLC } 3 \text { educators to discuss } \\
\text { their current students' } \\
\text { profiles and make } \\
\text { connections to the Zone } 3 \\
\text { content. }\end{array}$ \\
\hline Zone & -MM presentation and & -MM presentation and & -Presentation through MM \\
\hline
\end{tabular}


EVOLUTION OF A MODEL

\begin{tabular}{|c|c|c|c|}
\hline 3 & $\begin{array}{l}\text { discussion of district } \\
\text { teacher supports to help } \\
\text { provide equity for gifted } \\
\text { learners. } \\
\text {-Facilitate exploration of } \\
\text { practical and actionable } \\
\text { resources that support } \\
\text { gifted NAANIP learners } \\
\text { and provide opportunities } \\
\text { to put resources to use in } \\
\text { lesson planning with the } \\
\text { guidance of the facilitator } \\
\text { and in collaboration with } \\
\text { their PLC members. Ask } \\
\text { educators to try lessons } \\
\text { using the supports, reflect, } \\
\text { and report back at the next } \\
\text { PLC meeting. } \\
\text {-Facilitate discussion } \\
\text { regarding non-instructional } \\
\text { supports (e.g., mentorships, } \\
\text { affiliate groups) for } \\
\text { NAANIP gifted learners. }\end{array}$ & $\begin{array}{l}\text { discussion of district teacher } \\
\text { supports to help provide } \\
\text { equity for gifted learners. } \\
\text { Presentation extends to } \\
\text { tools that support equity in } \\
\text { gifted curriculum. } \\
\text {-Facilitator provides an } \\
\text { example of inequitable } \\
\text { curriculum from the district } \\
\text { and PLC engages in } \\
\text { modification activity, } \\
\text { identifying practical, } \\
\text { actionable ways to provide } \\
\text { resources in the classroom } \\
\text { to support NAANIP } \\
\text { students. } \\
\text {-Educators identify and } \\
\text { discuss frontloading and } \\
\text { talent development as a } \\
\text { practice in the early } \\
\text { identification of gifted } \\
\text { NAANIP students. } \\
\text {-Educators identify human } \\
\text { resources available within } \\
\text { their district and non- } \\
\text { instructional supports in } \\
\text { their local community who } \\
\text { can support gifted } \\
\text { programming and NAANIP } \\
\text { gifted learners. }\end{array}$ & $\begin{array}{l}\text { of tools that support equity } \\
\text { in gifted curriculum. } \\
\text {-PLC reviews and modifies } \\
\text { school and district gifted } \\
\text { curriculum for equity and } \\
\text { identifies practical, } \\
\text { actionable ways to provide } \\
\text { resources in the classroom } \\
\text { to support NAANIP gifted } \\
\text { learners. } \\
\text {-Facilitator and PLC } \\
\text { discuss the concept of } \\
\text { reparations and what/how } \\
\text { this looks like in gifted } \\
\text { education. } \\
\text {-PLC identifies human } \\
\text { resources available within } \\
\text { the districts who can } \\
\text { support the gifted } \\
\text { programming, as well as } \\
\text { community resources for } \\
\text { non-instructional supports. } \\
\text { Educators make and share } \\
\text { connections during the } \\
\text { PLC. } \\
\text {-Facilitator provides } \\
\text { opportunities for educators } \\
\text { to plan together, share } \\
\text { ideas, and for } \\
\text { demonstration teaching. }\end{array}$ \\
\hline $\begin{array}{c}\text { Zone } \\
4\end{array}$ & $\begin{array}{l}\text {-Facilitator presents } \\
\text { through MM the basic } \\
\text { tenets of FoK; focus on } \\
\text { strengths/assets-based } \\
\text { viewpoints and cultural } \\
\text { capital. } \\
\text {-Facilitator encourages PLC } \\
\text { to attend events within the } \\
\text { school community. } \\
\text {-PLC reviews current } \\
\text { parent and community } \\
\text { engagement opportunities } \\
\text { focused on gifted } \\
\text { programming; assess level } \\
\text { of impact and quality of }\end{array}$ & $\begin{array}{l}\text {-Facilitator trains PLC to } \\
\text { conduct home/community } \\
\text { visits and build asset-based } \\
\text { relationships with families } \\
\text { and the community, per the } \\
\text { FoK framework. } \\
\text {-PLC reviews current parent } \\
\text { and community engagement } \\
\text { opportunities focused on } \\
\text { gifted programming } \\
\text { assessing for level of impact } \\
\text { and quality of engagement. } \\
\text {-PLC engages community } \\
\text { members and develops a } 5 \\
\text { year plan for community }\end{array}$ & $\begin{array}{l}\text {-PLC continues to support } \\
\text { PLC } 1 \text { as needed but } \\
\text { moves more to engaging in } \\
\text { their own work. } \\
\text {-PLC conducts home visits } \\
\text { and builds asset-based } \\
\text { relationships with families } \\
\text { and the community, per the } \\
\text { FoK framework, with } \\
\text { facilitator guidance and } \\
\text { feedback. } \\
\text {-PLC works with } \\
\text { administration, parent, and } \\
\text { community members to } \\
\text { revise current parent and }\end{array}$ \\
\hline
\end{tabular}


EVOLUTION OF A MODEL

\begin{tabular}{|c|c|c|}
\hline $\begin{array}{l}\text { engagement. } \\
\text { - PLC with facilitator } \\
\text { guidance explores how to } \\
\text { engage the NAANIP } \\
\text { community in gifted } \\
\text { programming; uses FoK } \\
\text { and cultural capital/wealth } \\
\text { frames }\end{array}$ & $\begin{array}{l}\text { partnerships based on } \\
\text { community and cultural } \\
\text { assets. } \\
\text {-PLC invites parents and } \\
\text { community to information } \\
\text { sessions; PLC researches } \\
\text { expert speakers to invite } \\
\text { that will provide culturally } \\
\text { relevant input on the gifted } \\
\text { programming. }\end{array}$ & $\begin{array}{l}\text { community engagement } \\
\text { opportunities focused on } \\
\text { gifted programming, } \\
\text { assessing for level of } \\
\text { impact and quality of } \\
\text { engagement. } \\
\text {-PLC conducts information } \\
\text { and engagement sessions } \\
\text { for parents and } \\
\text { community. }\end{array}$ \\
\hline
\end{tabular}

At each zone, and in each professional learning community, the facilitator should provide time for self-reflective journaling prompts, discussions, and debriefs. Note that in Zone 2, PLCs one and two are combined. Differentiation for Zone 2 is based on the level of cultural awareness and equity knowledge the PLCs demonstrated after Zone 1. For example, the facilitator differentiates the case studies, scenarios, discussion questions, and reflective prompts, mirroring the appropriate level of proximal development of the educators, allowing for their growth. Table 3 shares selected resources that may be used during each of these zones.

Table 3

Zones in Action: Selected Sample Resources

\begin{tabular}{|c|l|}
\hline Zone & \multicolumn{1}{|c|}{ Selected Resources } \\
\hline $\begin{array}{c}\text { Zone } \\
\mathbf{1}\end{array}$ & -White Racial Identity and Anti-Racist Education: A Catalyst for Change by Sandra M. \\
& Lawrence and Beverly Daniel Tatum, https://bit.ly/3jDrJFg \\
& -Native Knowledge 360, Smithsonian, http://s.si.edu/3jCGFDy \\
& -Understanding Equity Literacy Webinar, Learning for Justice (formerly Teaching for \\
& Tolerance), http://bit.ly/374QN2F \\
\hline $\begin{array}{c}\text { Zone } \\
\mathbf{2}\end{array}$ & -Understanding, Identifying, and Meeting the Needs of Gifted Native American \\
& $\begin{array}{l}\text { Students, by Tamara Fisher. http://bit.ly/NAANIPTFA } \\
\text {-Exploring Critical Issues in Gifted Education: A Case Studies Approach, by Christine } \\
\\
\text { L. Weber, Cecilia Boswell, \& Wendy Behrens } \\
\\
\text {-How Oklahoma's identification of gifted Native students could serve as a national } \\
\text { model, article with audio interview, by Robby Korth, http://n.pr/3tMDQUZ }\end{array}$ \\
\hline
\end{tabular}


EVOLUTION OF A MODEL

\begin{tabular}{|c|l|}
\hline $\begin{array}{c}\text { Zone } \\
\mathbf{3}\end{array}$ & -Teacher Spotlight Case Studies, National Association for Multicultural Education, \\
& http://bit.ly/3rOv6vZ \\
& -Recruiting and Retaining Culturally Different Students in Gifted Education, by Donna \\
& -Approaches to Multicultural Curriculum Reform, by James Banks, \\
& https://bit.ly/2NgcvK8 \\
\hline $\mathbf{Z o n e}$ & -Equity Matters: Engaging Families through Home Visits, Learning for Justice, \\
$\mathbf{4}$ & $\begin{array}{l}\text { http://bit.ly/2MZpkc3 } \\
\text {-Reality Pedagogy: Teaching, Learning, Truth, and Distortions, TEDX talk by } \\
\text { Christopher Emdin, https://bit.ly/3jHgD1Y } \\
\text {-Funds of Knowledge for Teaching: Using a Qualitative Approach to Connect Homes } \\
\text { and Classrooms, Luis C. Moll, Cathy Amanti, Deborah Neff, Norma González, } \\
\text { https://bit.ly/3aVj1hJ }\end{array}$ \\
\hline
\end{tabular}

\section{Connecting the Pieces: What's Next?}

Local Norms. Multiple pathways to identification. Varied assessments and portfolio assessments. All are reasonable interventions in the fight against underrepresentation within gifted education, in the goal of equity. Looking through the lens of the theoretical frameworks of equity literacy and funds of knowledge, however, are strategies enough? The broken system goes beyond tests and pathways; it is steeped in structural inequities, founded in oppression and bias that cannot be assuaged by strategies. By focusing on deep knowledge of the community, bringing that knowledge into the schools, and educating stakeholders, the structure of the school can change, the system can change. The Four Zone Professional Model can be used school wide or district wide in order to foster change within the sphere of influence that surrounds the professional learning facilitator for gifted programs. It is not a matter of either/or; change needs both/and.

Using the Four Zone Professional Model is the starting point in the change process. It begins the educational journey. It fosters knowledge, creates acceptance, promotes wider beliefs in gifted cultural knowledge. Within the professional learning zones, learning is best approached 
EVOLUTION OF A MODEL

as embedded, collaborative, sustained, and ongoing (Darling-Hammond et al., 2009;

Gulamhussein, 2013; Troxclair et al., 2017) in order to be most effective in gifted professional learning. But with any activism work, beyond the learning is then the call to action. In the PDSA cycle, Planning requires a list of steps, action items, timetables, responsible parties... the professional learning is not the end of the work; it is the beginning.

\section{Future Directions}

The need for quality professional learning, for teachers and administrators, in all educational settings is acknowledged and supported by the United States federal government. Districts considering professional learning for their teachers have access to federal funds allocated by ESSA. Eligibility for these funds requires the professional learning to be valid and reliable enacting a change in teacher practice and/or beliefs. High quality professional learning which is targeted to a specific need along with outcomes which are measured have become the norm. Taking it one step further, the US Department of Education (US DOE) recognizes the importance of personalized professional learning plans which are targeted to the needs of the teachers. In April 2020, the US DOE proposed a new funding priority which would enable teachers to choose professional learning relevant to their personal need rather than the standardized all district professional learning sessions. In June 2020, The Consortium for Inclusion of Underrepresented Racial Groups in Gifted Education (I-URGGE) released a statement titled, “Get Your Knee Off Our Necks: Black Scholars Speak Out to Confront Racism Against Black Students in Gifted and Talented Education." Signed by thirteen scholars in the field of gifted education, the statement responded to the consistent police brutality, racism, and the inequities in gifted education for Black students. In July 2020, NAGC announced a vision statement that supported Black gifted learners, promoting equity and social justice. The initial 
EVOLUTION OF A MODEL

steps included town hall discussions, reviewing policies to prioritize equity, developing publications centering around Black gifted learners and expanding the Javits-Frasier Scholars Program which supports teachers through PL in Title I schools. Council for Exceptional Children-The Association for the Gifted (CEC-TAG) first published in 2001 as "Diversity and Developing Gifts and Talents: A Call to Action.” Initially updated and re-released in 2009, CECTAG recently updated and published "A Call to Action: Supporting Equity, Diversity, and Access for Gifted Students" in 2020. This document calls for strategic movement in professional learning, equitable access, curriculum and instruction that is culturally responsive, research focused in equity and diversity, parent engagement and community partnerships, and policy. As Sam Cooke (1964) emotes, "It's been a long, a long time coming; But I know a change is gonna come, oh yes it will."

Seeking to validate the theoretical Four Zone Professional Model, the authors partnered with several school districts and are currently in the process of evaluating the short-term and long-term success of the model in changing teacher perceptions and practices. Following the plan-do-study-act model, the researchers will continue to fine tune the Model. Professional learning is a cornerstone in achieving equity within gifted education, but it cannot be carried out in isolation. Together, educators, administers, researchers, students, and communities can be the change. 
EVOLUTION OF A MODEL

\section{References}

Alexander, F. (2018, October 12). How ESSA's shift in focus to professional learning affects teachers. Houghton Mifflin Harcourt. https://www.hmhco.com/blog/essas-shift-in-focusto-professional-development-how-it-affects-teachers

Amanti, C. (2005). Beyond a beads and feathers approach. In N. González, L.C. Moll, C. Amanti (Eds.) Funds of knowledge: Theorizing practices in households, communities, and classrooms (pp. 131-142). Routledge.

Brigandi, C.B., Gilson, C.M. \& Miller, M. (2019). Professional development and differentiated instruction in an elementary school pullout program: A gifted education case study. Journal for the Education of the Gifted, 42(4), 362-395.

Consortium for Inclusion of Underrepresented Racial Groups in Gifted Education. (2020, June 10). Get your knee off our necks: Black scholars speak out to confront racism against Black students in gifted and talented education. https://drive.google.com/file/d/1_BMZKWTsQsIFJNaTW-UOFmmNhh-5Vha6/view

Cooke, S. (1964). A Change is Gonna Come [Song]. On Ain't That Good News. Hugo \& Luigi. RCA Victor.

Council for Exceptional Children-The Association for the Gifted (2020). A call to action: Supporting equity, diversity, and access for gifted students. http://cectag.com/wpcontent/uploads/2020/12/Call-to-Action-2020.pdf

Darling-Hammond, L., Wei, R.C., Andree, A., Richardson, N, \& Orphanos, S. (2009). Professional learning in the learning profession: A status report on teacher development in the United States and abroad. Oxford, OH. National Staff Development Council. 
EVOLUTION OF A MODEL

Dixon, F. A., Yssel, N., McConnell, J. M., \& Hardin, T. (2014). Differentiated instruction, professional development, and teacher efficacy. Journal for the Education of the Gifted, 37, 111-127. https://doi-org.ezproxy.ycp.edu:8443/10.1177/0162353214529042

Every Student Succeeds Act, Pub. L. 114-95, S.1177, §8002.

King, K.A., Artiles, A.J., Kozleski, E.B. (2009). Professional learning for culturally responsive teaching. Equity Alliance Center. https://guide.swiftschools.org/sites/default/files/documents/Professional_Learning_for_C ulturally_Responsive_Teaching\%20\%281\%29.pdf

Kronborg, L., \& Plunkett, M. (2013). Responding to professional learning: How effective teachers differentiate teaching and learning strategies to engage highly able adolescents. Australasian Journal of Gifted Education, 22(2), 52-63.

Goings, R. B. \& Ford, D.Y. (2018). Investigating the intersection of poverty and race in gifted education journals: A 15 year analysis. Gifted Child Quarterly, 61(1), 25-36. DOI: $10.1177 / 001698621773761$

González, N., Moll, L.C., Amanti, C. (2005a). Introduction: Theorizing practices. In N. González, L.C. Moll, C. Amanti (Eds.) Funds of knowledge: Theorizing practices in households, communities, and classrooms (pp. 1-28). Routledge.

González, N., Moll, L.C., Amanti, C. (Eds.) (2005b). Funds of knowledge: Theorizing practices in households, communities, and classrooms. Routledge.

Gorski, P.C. (2020). Equity literacy principles. EdChange and the Equity Literacy Institute. http://edchange.org/handouts/Equity-Literacy-Principles.pdf

Gorski, P.C., \& Swalwell, K. (2015). Equity literacy for all. Educational Leadership,72(6) 3440. http://edchange.org/publications/Equity-Literacy-for-All.pdf 
EVOLUTION OF A MODEL

Gulamhussein, A. (2013). Teaching the teachers: Effective professional development in an era of high stakes accountability. The Center for Public Education. http://conference.ohioschoolboards.org/2017/wpcontent/uploads/sites/17/2016/07/1pm111317A114Job-embedPD.pdf

Hallet, R.E. \& Venegas, K.M. (2011). Is increased access enough? Advanced placement courses, quality, and success in low-income urban schools. Journal for the Education of the Gifted, 34, 468-487. Doi: 10.1177/016235321103400305

Lewis, K.D., Novak, A.M, \& Coronado, J. (2015). Teachers' perceptions of characteristics of gifted Hispanic Bilingual students: Perspectives from the border." Texas Forum of Teacher Education, 5, 71-91.

Lewis, K.D., \& Novak, A.M. (2019a). Identifying and supporting culturally, linguistically and economically diverse gifted learners: Guiding teachers through the four zones of professional learning. In A.M. Novak \& C.L. Weber (Eds.), Best practices in professional learning and teacher preparation: Special topics for gifted professional development (Vol. 2) (pp. 133-158). Prufrock Press.

Lewis, K.D., \& Novak, A.M. (2019b, July 24-28). Professional learning and families: Working with teachers to create learning opportunities for parents [Conference session]. World Conference on the Gifted and Talented, Nashville, TN, United States.

Lewis, L.C., Rivera, A. \& Roby, D. (2012). Identifying and serving culturally and linguistically diverse gifted students. Prufrock Press.

Moen, R.D., \& Norman, C. L. (2010). Circling back. Quality Progress, 43 (11), 22-28. 
EVOLUTION OF A MODEL

Moll, L.C. (2005). Funds of distributed knowledge. In N. González, L.C. Moll, C. Amanti (Eds.) Funds of knowledge: Theorizing practices in households, communities, and classrooms (pp. 275-287). Routledge.

Miller, E. M. (2009). The effect of training in gifted education on elementary classroom teachers' theory-based reasoning about the concept of giftedness. Journal for the Education of the Gifted, 33, 65-105. https://doiorg.ezproxy.ycp.edu:8443/10.1177/016235320903300104

National Association for Gifted Children. (2011). Position statement: Identifying and serving culturally and linguistically diverse gifted students. https://www.nagc.org/sites/default/files/Position\%20Statement/Identifying\%20and\%20Se rving\%20Culturally\%20and\%20Linguistically.pdf

National Association for Gifted Children. (2019). Standard 6: Professional development: Ensuring student outcomes for professional development with evidence-based practices. https://www.nagc.org/resources-publications/resources/national-standards-gifted-andtalented-education/pre-k-grade-12-6

National Association for Gifted Children. (n.d.). Classroom instruction and teacher training for gifted students from diverse populations. https://www.nagc.org/resourcespublications/resources/timely-topics/ensuring-diverse-learner-participation-gifted-1

National Association for Gifted Children- Council for Exceptional Children. (2013). NAGC-CEC teacher preparation standards in gifted and talented education. https://www.nagc.org/sites/default/files/standards/NAGC\%20CEC $\% 20$ CAEP $\% 20$ standards $\% 20$ (2013\%20final).pdf 
EVOLUTION OF A MODEL

National Association for Gifted Children (2020, July 22). Next steps in NAGC's equity and social justice initiative. [Blog]. https://www.nagc.org/blog/next-stepsnagc $\% \mathrm{E} 2 \% 80 \% 99$ s-equity-and-social-justice-initiative

National Center for Education Statistics. (2018). Percentage of public school students enrolled in gifted and talented programs, by sex, race/ethnicity, and state: Selected years, 2004 through 2013-14. Digest of Education Statistics. https://nces.ed.gov/programs/digest/d17/tables/dt17_204.90.asp

Novak, A.M. \& Jones, K.D. (2020). Gatekeepers in gifted: A case study of the disproportionality of gifted black youth in elementary program. Journal of Cases in Educational Leadership, 1-17. https://doi.org/10.1177/1555458920976736

Novak, A.M., \& Lewis, K.D. (2015, November 13-15). Equity and Access in Gifted Programming for Hispanic Youth: Targeted Professional Development for Teachers [Conference session]. National Association for Gifted Children Convention, Phoenix, AZ.

Novak, A.M., \& Lewis, K.D. (2018, November 15-18). Equity and access in k-12 gifted and the need for targeted professional learning for teachers [Conference session]. National Association for Gifted Conference, Minneapolis, MN, United States.

Novak, A.M., \& Lewis, K.D. (2019, July 24-28). Guiding the Gatekeepers: Using Professional Learning to Promote Equity and Access in K12 Gifted Education [Conference session]. World Conference on the Gifted and Talented, Nashville, TN, United States.

Novak, A.M., \& Lewis, K.D. (2021, March 8-13). Four zones of professional learning: 
EVOLUTION OF A MODEL

Fostering equity in gifted programs. [Conference session]. Council for Exceptional Children Convention. Virtual. https://exceptionalchildren.org/convention/registration/schedule-glance

Novak, A.M., Lewis, K.D., \& Weber, C.L. (2020). Guiding principles in developing equity-driven professional learning for educators of gifted students. Gifted Child Today 43(3), 169-183.

Partelow, L., Spong, A., Brown, C., Johnson, S. (2017). America needs more teachers of color and a more selective teaching profession. Center for American Progress. https://www.americanprogress.org/issues/education-k12/reports/2017/09/14/437667/america-needs-teachers-color-selective-teachingprofession/

Peters, S.J., Jolly, J.L. (2018). The influence of professional development in gifted education on the frequency of instructional practices. Australian Educational Researcher 45, 473-491 https://doi-org.ezproxy.ycp.edu:8443/10.1007/s13384-018-0260-4

Tague, N.R. (2005). The quality toolbox (2nd ed.). Milwaukee, WI: ASQ Quality Press.

Troxclair, D., Shaunessy-Dedrick, E., \& Mursky, C. (2017). Designing professional development activities. In S. Johnsen \& J. Clarenbach (Eds.), Using the national gifted education standards for pre-k-grade 12 professional development ( $2^{\text {nd }} \mathrm{ed}$.) (pp. 109-126). Prufrock Press.

U.S. Department of Education. (2020, April 15). Secretary DeVos proposes rethinking teacher professional development by empowering teachers to customize, personalize their continued learning [Press release] https://www.ed.gov/news/press-releases/secretary- 
EVOLUTION OF A MODEL

devos-proposes-rethinking-teacher-professional-development-empowering-teacherscustomize-personalize-their-continued-learning

Weber, C. L., Novak, A.M., \& Lewis, K.D. (2018). What's in a name? Professional development vs. professional learning. NAGC Insider. National Association for Gifted Children. https://www.nagc.org/whats-name

\section{Author Biographies}

Angela Novak, Ph.D., is an Assistant Professor and AIG Coordinator at East Carolina University. She teaches undergraduate and graduate courses in education, focusing on assessment practices and gifted education. Dr. Novak has served NAGC and CEC-TAG in a variety of network, committee and board roles, and co-edited, with Christine Weber, a series of NAGC service publications related to professional learning. She has worked in public education in the gifted field as a classroom teacher, resource teacher, and central office support, as well as in the private not-for-profit sector of gifted education. She is an equity advocate, and is a member of the Diversity Scholars Network, from the National Center for Institutional Diversity (NCID) and is currently the Co-Chair of the Diversity and Equity Committee for NAGC.

Katie D. Lewis, Ed.D., is an associate professor at York College of Pennsylvania, formerly of Texas A\&M International University. She teaches undergraduate early elementary education courses, and she also serves as program coordinator for Secondary Education, PostBaccalaureate and Transfer students. Dr. Lewis has 5 years of experience teaching in public schools where she served as grade chair, lead science teacher, gifted cluster teacher and mentor 
EVOLUTION OF A MODEL

to student teachers. She serves as Past-Chair for the TAGT Research Division and NAGC Professional Learning Network.

\author{
Angela M. Novak \\ Assistant Professor and Academically and Intellectually Gifted (AIG) Coordinator \\ Department of Elementary and Middle Grades Education, College of Education \\ East Carolina University \\ Speight 311, Mailstop 504, Greenville NC 27858 \\ 252-328-6649,novaka17@ecu.edu \\ Home Address: 920 Hosta Valley Ct Wake Forest NC 27587
}

Katie D. Lewis

Associate Professor of Education

Department of Education, School of Behavioral Sciences and Education

York College of Pennsylvania

441 Country Club Rd, York, PA 17403

717-815-2085, klewis15@ycp.edu

Home Address: 815 Tenby Court, York, PA 17402 